Journal of Social Sciences 8 (1): 104-108, 2012

ISSN 1549-3652

(C) 2012 Science Publications

\title{
Modelling Political Support among Women with Political Actors in Northern States
}

\author{
${ }^{1}$ Zaherawati Zakaria, ${ }^{2}$ Kamarudin Ngah, ${ }^{3}$ Jamaludin Mustaffa, \\ ${ }^{4}$ Nazni Noordin, ${ }^{5}$ Mohd Zool Hilmie Mohamed Sawal and ${ }^{6}$ Zuriawati Zakaria \\ ${ }^{1}$ Department of Administrative Science and Policy Studies, \\ University Technology MARA, Merbok, Kedah Malaysia \\ ${ }^{2}$ Pusat Penyelidikan Dasar dan Kajian Antarabangsa (CenPRIS), \\ University Sains Malaysia (USM), Pulau Pinang, Malaysia \\ ${ }^{3}$ Department of Arts and Science, \\ University Utara Malaysia, 06010 Sintok, Kedah, Malaysia \\ ${ }^{4}$ Faculty of Administrative Science and Policy Studies, \\ University Technology MARA, P.O. Box 187, 08400 Merbok, Kedah, Malaysia \\ ${ }^{5}$ Department of Information Management, \\ University Technology MARA, 08400 Merbok, Kedah Malaysia \\ ${ }^{6}$ Department of Finance, Faculty of Business and Finance, \\ University Tunku Abdul Rahman, Kampar Jalan University, \\ Bandar Barat, 31900 Kampar, Perak, Malaysia
}

\begin{abstract}
Problem statement: Women in Asia are making their mark with distinct styles of leadership, but have a long way to go to reach the critical mass needed to level a political playing field that remains much easier for men to take part. Yet far from being included in the decision-making process, women find themselves under-represented in political institutions. Approach: Numerous challenges confront women entering politics. Many feel that Malaysian society is still male dominated and men are threatened by the idea of women holding senior posts. Thus the objective of this study tries to identify the model of political support of women by looking at relationship with political parties in the northern states. The result of findings shows that there is a significant relationship between them. Results: The recommendations were proposed such as women should be more participate in political parties activities from the women wings from the grass-root and women representatives should be given more opportunities in voice their idea as men in political arena. Conclusion: In future research, political parties and government should open widely the platform for women active in politics and give them an opportunity to exercise the political power as men earned in decision-making process.
\end{abstract}

Key words: Political actors, decision-making process, increasing participation, engaged themselves, indigenous peoples, providing solid, mainstream party, political parties, possible meanings

\section{INTRODUCTION}

Having effective women leaders may well be a resource that Asia would find useful as it copes with rapid urbanisation and its woes-health, crime and environment problems. This challenge will continue as the number of Asians living in cities is expected to rise from $37 \%$ today to $55 \%$ by 2025 , CENPRIS 2003 says, so there is a need for new ways to work toward liveable cities. This, he adds, is an area where women's leadership priorities usually lie and women leaders often focus more on the environment, human development and building sustaining communities. From the time of Independence in 1957, Malaysian women have had the right to vote and to hold office. Today women comprise one half of the registered voters and are active in political life. The trends of participation among women members of various political parties do not show significant differences among them. Women have continued being loyal

Corresponding Author: Zaherawati Zakaria, Department of Administrative Science and Policy Studies, University Technology MARA, Merbok, Kedah Malaysia Tel: +604-4562565 


\section{J. Social Sci., 8 (1): 104-108, 2012}

supporters of political parties in Malaysia. Members of the Wanita UMNO in 1971 have continued to gain wide recognition for their prominent role amongst women's political organizations in Malaysia. These party members are regarded as the very backbone of the UMNO party. However, women have continued the trend of providing solid support for male leaders and have engaged themselves primarily in raising financial support for the parties.

On the basis of data from the states of Johor, Kelantan, Terengganu, similar trends are to be found. In 1993, women were even less visible in state assemblies. At the national level, women's representation is still relatively low. Women's participation in decision making positions in government ministries is similar. Women's participation in government service has increased rapidly between 1980 and 1991, from 27$33.6 \%$. Several factors are important in this regard, the most significant being women's increasing participation in education (Linde, 2004). It was also in part due to the expansion of the health and education sectors and the increased opportunities in government service for teachers and health workers.

There is a positive correlation between the educational attainments of women and their labour force participation rates. Women have increasingly opted to join the government services. This has to do with the expansion of government employment from the 1960s until the 1980s, during which period, government extended its scope to include support services to provide for the rapid social and economic development of the nation. Women's entry into government service also helps illustrate attitudinal changes among parents, who recognize that girls have educational and professional potential, which provides options for them outside of marriage (Ariffin, 1994).

In Malaysia, the constraint in building people's solidarity is the situation that we are a multi-ethnic society. Malaysians are composed of Malays, Chinese, Indians and Indigenous Peoples. Identity politics fuelled by political parties based on ethnicity, state policies and rhetoric get in the way and divide us. As a result, we tend to view each other with suspicion. Gaining a more democratic space that accommodates women organizing in Malaysia will only be possible when ordinary people-students, workers, the urban poor, rural people, indigenous peoples and many other groups transcend ethnic, sexual and other kinds of identities-and unite (Mazur, 2005).

However, today the state has appropriated the issue for itself. But when women become more political, for example when they speak out on human rights issues, question police violence or are critical of the nature of development in the country, then we are faced with the dilemma of whether to just accept this untenable situation or struggle within whatever existing space is left can be seen as below:

"There are at least five factors that form obstacles to Malaysian women's active participation in politics: subliminal discrimination against women; time constraints; the notion that "a woman's place is at home"; natural apathy and aversion to political involvement and lack of adequate resources Rashila (2000).

According to above statement, it explains at least five common factors which form obstacles to Malaysian women's active participation in politics. They classify the factors as, social discrimination against women's roles in the public domain, time constraints due to career and domestic demands, cultural and religious arguments that a woman's place is at the home, structural constraints within each political party that do not allow women to advance beyond a certain level and lack of adequate resources in terms of organizational support, personal influence and finance. Another challenge faced is women's membership in all political parties in Malaysia is also in the sidelines and not in the mainstream party. Women wings in political parties remain secondary to men despite them fulfilling crucial grass roots role during the campaigning period of each general election. While men in the party's youth wings can 'climb up' the party hierarchy into the mainstream party, women seems to be constrained within their respective wings perpetually playing a supportive and secondary role to their male counterparts. There still exists a significant gender gap or gender inequality both in Malaysia when one reviews all the areas of modern life. Thus, this research tries to identify the relationship between political actors with women in model of political support among them.

Literature review: From the time of Independence in 1957, Malaysian women have had the right to vote and to hold office. Today women comprise one half of the registered voters and are active in political life. The trends of participation among women members of various political parties do not show significant differences among them. Women have continued being loyal supporters of political parties in Malaysia. Members of the Wanita UMNO in 1971 have continued 


\section{J. Social Sci., 8 (1): 104-108, 2012}

to gain wide recognition for their prominent role amongst women's political organizations in Malaysia Rashila, 2000). However, women have continued the trend of providing solid support for male leaders and have engaged themselves primarily in raising financial support for the parties (Wan, 2000). Women members turn out in full force during election campaigns and carry out routine tasks related to daily campaigning and facilitating voter participation during the election process. Despite the significant roles played by the Wanita UMNO and the other women's auxiliaries at the level of mass politics, the representation of women as branch or division heads is limited. In 1993, 5 out of 30 members $(17 \%)$ of the central committee were women and out of 153 divisions only one is headed by a woman. None of the 14,784 branches is headed by a woman. For more than forty-five years, the women's auxiliary of UMNO has only three women heads of divisions (Ariffin, 1994).

From available data on local councils from five $\mathrm{v}$ in Peninsular Malaysia, (Selangor, Penang, Johor, Kelantan and Terengganu), the number of women councillors for the period 1988-93 is insignificant in comparison to male councillors. Women's representation in Penang local authorities has not changed significantly since 1988 . On the basis of data from the states of Johor, Kelantan, Terengganu, similar trends are to be found. In 1993, women were even less visible in state assemblies. At the national level, women's representation is still relatively low. Women's participation in decision making positions in government ministries is similar. Women's participation in government service has increased rapidly between 1980 and 1991, from 27-33.6\%. Several factors are important in this regard, the most significant being women's increasing participation in education. It was also in part due to the expansion of the health and education sectors and the increased opportunities in government service for teachers and health workers (Rashila, 2000).

Political support is a concept with many possible meanings and, accordingly, a wide variety of definitions can be found in the literature. One of the most frequently used definitions is provided by Easton (1975), who defines support as 'an attitude by which a person orients himself to an object favorably or unfavorably, positively or negatively'. In the field of comparative politics, research on political support has been closely connected with research on political attitudes and political culture. Almond and Verba
(1963) referred to political attitudes as the political culture of a nation. Political culture includes everything from beliefs in the legitimacy of the political system to attitudes towards the appropriateness of political input structures and government policies (Rai, 1999). In a recent contribution to political culture studies, Pippa Norris and some other prominent scholars have developed David Easton's three-fold distinction between different objects of support-the political community, the regime and the authorities-into a fivefold model of political support (Norris, 1999).

\section{MATERIALS AND METHODS}

The researchers have chosen survey and crosssectional surveys as the research design. Quantitative method used in order to have better understanding the relationship between political communities with political support of women in northern states. The population was among voters above 21 years in Kedah, Penang and Perlis. The sample for this study comprised of 780 respondents and the breakdown of the respondents based on state is $280(25.6 \%)$ from Perlis, $300(38.5 \%)$ from Kedah and 280(35.9\%) from Penang. In order to analyze the data, the statistical techniques used are Descriptive Statistic and Pearson Correlation.

\section{Findings:}

Profile of respondents: In this profile of respondents, the researchers discuss about the respondents demographic such as age, marital status, race and respondent's income. It indicates that most of the respondents are in the age of 21-29 years old which recorded $238(30.5 \%)$. This been followed with the group age of 30-39 years old recorded 231 (29.6\%). The study also indicate the lowest been recorded is the group age of 70-79 years old. From the result, most of the respondent that took part in this research are youth which the range of 21-39 years old. Reason behind these results possibly the high awareness of youth groups toward the political movements in the northern region. From the study, it shows the marital status of the respondents which most of the respondents were married status with recorded as 474 (60.8\%). This followed by single status with 251 (32.2\%). Instead that figure, it also indicates the lowest respondents were widow status with 55 (7.1\%). Furthermore, it shows the race of the respondents which indicated that the highest race participated in this research are among Malay respondent recorded $494(63.3 \%)$. This followed by 


\section{J. Social Sci., 8 (1): 104-108, 2012}

Chinese respondents with recorded 163 (20.9\%). There are also stated others race which include the race like Iban, Kadazan and other indigenous groups in Malaysia with $4(0.5 \%)$ which the lowest participants.

The reason highest percentage in Malay respondents because the study has been done in Northern states which most of the Malay society live in this region. The results show that most of the respondents income are in the range of RM 1001-RM 3000 with 381 (48.8\%). This been followed closely by respondents income that below RM 1000 with 185 (23.7\%). It also indicated that respondents income above RM 10001 only $5(0.6 \%)$ which is results a small percentage. High percentages in income range RM 1001-RM 3000, because of the respondents were worked as government servant and private workers. Nevertheless, the results also indicated no income level which is $45(5.8 \%)$ due to some of them were housewives.

In next results, it shows the level of political support among the women in the political activities. Results remarked the not active in the political support as the highest with 557 (71.4\%). There also indicate the results of very active in the political support among women participants with a small size with 39 (5\%). While for the active group it was resulted 184 (23.6\%). As described, 692 (88.7\%) respondents has involved in politics in the form as voter while $88(11.3 \%)$ respondents has never done as voter in political activities. This is not surprising finding as it has been proven in many previous study that form of voter is the popular support in political activities. Furthermore, more respondents have never support in politics as a candidate which represents 755 (96.9\%) while 2.5 $(3.2 \%)$ have direct support in politics as a candidate. It shown that northern region still has the lower support in the form as candidate among women.

\section{RESULTS}

The pearson correlation obtained for the eight intervals scaled variables shown as indicated as follows:

Hypothesis 1: There is a significant relationship between the political actors and political support among northern region women.

Table 1 shows there is a significant relationship between Political Actors and political support of women where $\mathrm{p}<0.01(\mathrm{p}=0.000)$ and $\mathrm{r}=0.421$. So, the researcher accepted the $\mathrm{H} 1$
Table 1: The relationship between political actors and political support of women

\begin{tabular}{lcc}
\hline & Political support & Political actors \\
\hline Pearson correlation & 1 & $0.421\left(^{*}\right)$ \\
Sig. (2-tailed) & $\cdot$ & 0.000 \\
$\mathrm{~N}$ & 780 & 780.000 \\
\hline Correlation is significant at the 0.01 level (2-tailed) &
\end{tabular}

\section{DISCUSSION}

Political actors has a positive relationship with political support of women: An analysis through the experiences of the respondents in northern states reveals that the political actor has significant and positive relationship towards political support. Therefore sense of belongingness and general willingness to involve in political associations were creating political support in northern region. Feminist groups have sense and an intention to join political associations was an important element to support the national political system. This is because within the community, the individual willingness to bond in the association or political parties for supports the political agenda. With these impressive findings, it is expected that most of the respondents were satisfied and agreed that actors played a major role in influencing them to support in politics even in different of political actors and views. This study clearly indicates the influence of intention, belief and political actors within the particular actors will encourage the political support toward ruling government. The existence of political actors and cooperation should be practiced to ensure a survival of the political system (democratic) within the state.

\section{Recommendations:}

Empower the women with political knowledge: Knowledge and understanding about the political views is needed in order to encourage women to support more actively and effectively. In this light, the government and other stakeholders have a role in guiding them in understanding form of support in politics. The government, especially the respective federal and states government, do carry out briefings at the start of a new term of political support. Women should be more knowledgeable in politics from upper to lower level and this responsibility usually complemented by the state governments' efforts in conducting seminars related to its machinery.

Seek supports from a broad range of women's perception: It is important for government to have a comprehensive understanding on the various form of support in politics by women in its agenda. Women should not be treated as one single entity as there are 
different roles with men. Some may oppose emotionally in support the political activities and some may support as voter or involved in talks, campaigns, lobbyist, but normally those who walk the loudest will get the attention. The federal and states ruling parties should also take account the existence of organized and unorganized public and whose interest do they represent.

\section{CONCLUSION}

Political support model has emphasized the importance and benefits of support for democratic decision making. On the same note, there is a abundant of literature over time that produces models and typologies to describe level of political support, with commonly referred to being Norris and David Easton model of political support. Yet, many studies on political support conclude that achieving effective political support is quite subjective and sensitive to be discussed easily and an elusive reality. As this case revealed, political actors regime is indeed a factor that correlates women with the interest to support in politics. To sum up, women needs collaboration and for engage more to support effectively in politics, they need to blend well with social interactions accordingly in order to achieve common goals and objective. Therefore, a part of focusing on improving political support process, future policies on empower women in decision making process also should be directed by federal and states ruling parties.

\section{REFERENCES}

Almond, G.A. and S. Verba, 1963. The Civic Culture: Political Attitudes and Democracy in Five Nations. 1st Edn., Princeton University Press, Princeton N. J., pp: 562 .
Ariffin, J., 1994. Reviewing Malaysian Women's Status: Country Report in Preparation for the Fourth UN World Conference on Women. 1st Edn., Population Studies Unit, University of Malaysia, Kuala Lumpur, ISBN: 9839705504, pp: 173.

Easton, D., 1975. A re-assessment of the concept of political support. Br. J. Political Sci., 5: 435-457. DOI: 10.1017/S0007123400008309

Linde, J., 2004. Doubting democrats?: A Comparative Analysis of Support for Democracy in Central and Eastern Europe. 1st Edn., Orebro University, Orebro, ISBN: 9176684083, pp: 291.

Mazur, M.A., 2005. The weevils (Coleoptera: Curculionoidea) of exothermic habitats of Silesia region (S Poland). Wiad. Entomol., 24: 175-178.

Norris, P., 1999. Critical Citizens: Global Support for Democratic Government. 1st Edn., Oxford University Press, Oxford, ISBN: 0191522341, pp: 320.

Rai, S.M., 1999. Democratic institutions, political representation and women's empowerment: The quota debate in India. Democratization, 6: 84-89. DOI: 10.1080/13510349908403622

Rashila, R., 2000. Political Modernization: Gender Equality in Political Participation? In: Country, Market and Modernization, Embong, A.R., (Ed.). UKM Press, pp: 198-213.

Wan, A., 2000. Perempuan dalam Politik: Refleksi dari Malaysia. Asuhan Keperawatan, WordPress. 